\title{
PROTOTYPE GENERATOR DC DENGAN PENGGERAK TENAGA ANGIN
}

\author{
Wan Novri Saputra, Dikpride Despa, Noer Soedjarwanto, Ahmad Saudi Samosir \\ Jurusan Teknik Elektro Universitas Lampung \\ Jl. Prof. Sumantri Brojonegoro No. 1 Bandar Lampung 35145 \\ novrigtl@gmail.com
}

\begin{abstract}
Abstrak
Angin merupakan salah satu sumber energi listrik. Untuk menghasilkan energi listrik dari angin dapat menggunakan alternator atau generator untuk mengonversi energi gerak menjadi energi listrik. Oleh karena itu, perlu dirancang sebuah prototype yang dapat digunakan sebagai referensi pemanfaatan sumber energi angin untuk menghasilkan energi listrik. Rancangan prototype ini menggunakan baling-baling yang terkopel dengan generator dan sistem utama yaitu sensor rotary encoder, sensor arus, dan sensor tegangan. Untuk pemrosesannya menggunakan modul Arduino Uno dan penyimpanan data menggunakan modul data logger. Sedangkan untuk pengambilan data menggunakan sepeda motor dengan memanfaatkan tekanan angin pada saat sepeda motor berjalan. Hasil pengujian didapatkan persamaan hubungan antara perbandingan tegangan uji dengan tegangan perhitungan terhadap kecepatan putaran rotor generator, yaitu $\mathrm{y}_{\mathrm{uji}}=0,007 \mathrm{x}+0,004$ dan $\mathrm{y}_{\text {perhitungan }}=$ $0,011 \mathrm{x}-2,844$ dengan persentase rata-rata eror adalah $15,04 \%$.Untuk persamaan hubungan antara perbandingan arus uji dengan arus perhitungan terhadap kecepatan putaran rotor pada generator, yaitu $\mathrm{y}_{\mathrm{uji}}=0,000 \mathrm{x}+0,0415$ dan $\mathrm{y}_{\text {perhitungan }}=0,002 \mathrm{x}-0,498$ dengan persentase rata-rata eror adalah $31,09 \%$.Sedangkan untuk hubungan kecepatan putaran rotor generator terhadap kecepatan sepeda motor (untuk kecepatan sepeda motor $\geq 30 \mathrm{~km} / \mathrm{jam}$ )didapatkan persamaan $y=25,40 x-342,9$.
\end{abstract}

Kata Kunci: Angin, Prototype Generator dc, Rotary Encoder, Arduino Uno, Data Logger.

\begin{abstract}
The wind is one source of electrical energy. To generate electricity from wind energy can be used alternator or generator to convert the mechanical energy into electrical energy. Therefore, it is necessary to design a prototype that can be used as a reference utilization of wind energy to generate electricity. The design of this prototype using a propeller which is coupled to the generator and the main system. This main system consists of sensor Rotary Encoder, current sensors and voltage sensors. For its processing is used Arduino Uno module and data logger module as data storage. As for data acquisition using a motorcycle by utilizing the wind pressure when the motorcycle moving. The test results obtained equation relationship between the ratio of experimental voltage to the calculated voltage of the rotor speed, which is $\mathrm{Y}_{\text {experiment }}=0,007 \mathrm{X}+0,004$ and $\mathrm{Y}_{\text {calculation }}=0,011 \mathrm{X}-2,844$ with percentage of average error $15.04 \%$. For equation the relationship between the ratio experimental current with the calculated current of the rotation speed of the generator rotor (rpm). Obtained equation $\mathrm{Y}_{\text {experiment }}=0,000 \mathrm{X}+0.0415$ and $\mathrm{Y}_{\text {calculation }}=0,002 \mathrm{X}-0,498$ with percentage of average error $31.09 \%$. As for the relationship of the generator rotor rotation speed to motorcycle speed (for motorcycle speed $\geq 30 \mathrm{~km} / \mathrm{h}$ ) obtained equation $\mathrm{y}=25,40 \mathrm{x}-342.9$.
\end{abstract}

Key words : Wind, Prototype Generator dc, Rotary Encoder, Arduino Uno, Data Logger. 


\section{PENDAHULUAN}

Penggunaan bahan bakar minyak dalam kehidupan sehari-hari dapat diemukan dimana saja, sepertiperalatan rumah tangga, alat perkantoran, pabrik, kendaraan, dan lain-lain. Dari sumber Ditjen MIGAS diketahaui bahwa cadangan minyak bumi dan produksinya setiap tahunya mengalami penurunan. Oleh sebab itu harus dapat menciptakan sumber energi baru untuk menguragi penggunaan bahan bakar setiap harinya.Pada dasarnya sumber energi listrik tidak dapat diperbaharui. Apabila manusia tidak dapat menggunakannya secara efektif dan efisien, maka energi listrik akan cepat habis. Semua peralatan yang menggunakan energi listrik akan membutuhkan energi lagi demi kelangsungan pemakaianya.

Generator merupakan sebuah alat yang memproduksi energi listrik dari energi mekanik dan biasanya menggunakan induksi elektromagnet dalam sistem kerjanya.Generator terdiri dari bebagai jenis dankegunaannya, salah satu diantaranya generator pada kendaraan yangdisebut alternator. Alternator memiliki sistem kerja yang sama dengan generator, kinerja dari alternator melingkupi daerah proses kerja pada sebuah kendaraan. Dimana alternator berfungsi untuk mensuplay arus listrik untuk keperluan kendaraan. Dalam kendaraan bermotor baterai atau aki kendaraan tidak akan mampu menyuplai arus listrik kekendaraan sendirian. Sifat baterai adalah sebagai penampung listrik yang dihasilkan dari alternator. Pada saat mesin kendaraan dinyalakan, maka alternator akan bekerja untuk menghasilkan listrik menggantikan fungsi baterai atau aki.

Jadi untuk menghemat sumber energi listrik atau bahan bakar kita dapat memanfaat tenaga angin untuk memutar alternator, yaitu dengan energi gerak menjadi listrik. Energi listrik yang dihasilkan dapat dimanfaatkan untuk keperluan sehari-hari, juga tidak menimbulkan polusi dan ramah lingkungan.

\section{TINJUAN PUSTAKA}

\subsection{Generator Arus Searah (DC)}

Generator arus searah mempunyai komponen dasar yang umumnya hampir sama dengan komponen mesin-mesin listrik lainnya. Secara garis besar generator arus searah adalah alat konversi energi mekanis berupa putaran menjadi energi listrik arus searah. Energi mekanik digunakan untuk memutar kumparan kawat penghantar di dalam medan magnet. Berdasarkan hukum Faraday, pada kawat penghantar akan timbul ggl induksi yang besarnya sebanding dengan laju perubahan fluksi yang dilingkupi oleh kawat penghantar. Bila kumparan kawat tersebut merupakan rangkaian tertutup, maka akan timbul arus induksi. Perbedaan setiap generator biasanya terletak pada komponen penyearah yang terdapat didalamnya yang disebut dengan komutator dan sikat[3].

\subsection{Sensor Arus Listrik ACS712}

Perangkat ACS712 ini terdiri dari rangkaian sensor efek-hall yang linier lowoffset dan p sisi. Saat arus mengalir dijalur tembaga pada bagian pin 1-4 seperti pada gambar. 2.1, maka rangkaian sensor efek-hall akan mendeteksinya dan mengubahnya menjadi tegangan yang proporsional.

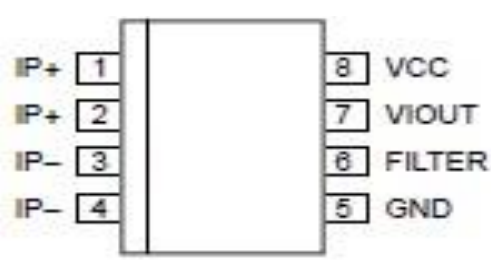

Gambar 2.1. Konfigurasi pin dari IC ACS712[10].

Berikut ini adalah karakteristik dari sensor suhu ACS712[10].

a. Memiliki sinyal analog dengan sinyal-ganguan rendah low-noise

b. Ben-bandwidth $80 \mathrm{kHz}$

c. Total output error $1.5 \%$ pada $\mathrm{Ta}=$ $25^{\circ} \mathrm{C}$

d. Memiliki resistansi dalam $1.2 \mathrm{infl}$

e. Tegangan sumber operasi tunggal $5.0 \mathrm{~V}$

f. Sensitivitas keluaran: 66 sd 185 $\mathrm{mV} / \mathrm{A}$

g. Tegangan keluaran proporsional terhadap arus AC ataupun DC

h. Fabrikasi kalibrasi 
i. Tegangan offset keluaran yang sangat stabil

j. Hysterisis akibat medan magnet mendekati nol

k. Rasio keluaran sesuaitegangan sumber

\subsection{Pembagi Tegangan}

Pada dasarnya rangkaian pembagi tegangan terdiri dari dua buah resistor yang dirangkai secara seri. Rangkaian pembagi tegangan dapat dilihat pada gambar. 2.2.

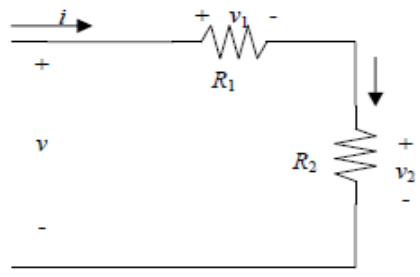

Gambar. 2.2. Rangkaian Pembagi Tegangan[5].

Aturan pembagi tegangan sangat sederhana, yaitu tegangan input dibagi secara proposional sesuai resistansi dua resistor yang dirangkai secara seri. Dari gambar. 2.2. didapat persamaan pembagi tegangan sebagai berikut[5]:

$v_{2}=R_{2} i=R_{2} \frac{v}{R_{1}+R_{2}}$

$$
\begin{gathered}
\text { Atau } \\
v_{2}=\frac{R_{2}}{R_{1}+R_{2}} v
\end{gathered}
$$

dan dengan cara yang sama, didapatkantegangan yang melintasi $R_{1}$ adalah[5]:

$$
v_{1}=\frac{R_{1}}{R_{1}+R_{2}} v
$$

Bila rangkaian pada Gambar 2.2. digeneralisir dengan menggantikan $R_{2}$ dengan $\mathrm{R}_{2}, \mathrm{R}_{3}, \mathrm{R}_{\mathrm{N}}$ yang berhubungan seri, maka didapat hasil umum pembagian tegangan melintasi suatu untaian $\mathrm{N}$ tahanan seri adalah[5].

$$
v_{1}=\frac{R_{1}}{R_{1}+R_{2} \ldots+R_{N}} v
$$

\subsection{Sensor Rotary Encoder}

Sensorrotary encoder inipada umumnya menggunakan sensor optik untuk menghasilkan serial pulsa yang dapat diartikan menjadi gerakan, posisi, dan arah. Sehingga posisi sudut suatu poros benda berputar dapat diolah menjadi informasi berupa kode digital oleh Rotary Encoder untuk diteruskan oleh rangkaian kendali. Rotary Encoder umumnya digunakan pada pengendalian robot, motor drive, dsb.

Rotary encoder tersusun dari suatu piringan tipis yang memiliki lubanglubang pada bagian lingkaran piringan. LED ditempatkan pada salah satu sisi piringan sehingga cahaya akan menuju kepiringan. Disisi yang lain suatu phototransistor diletakkansehingga phototransistor ini dapat mendeteksi cahaya dari LED yang berseberangan. Piringan tipis tadi dikopel dengan poros motor, atau divais berputar lainnya yang ingin kita ketahui posisinya, sehingga ketika motor berputar piringan juga akan ikut berputar. Apabila posisi piringan mengakibatkan cahaya dan LED dapat mencapai photo-transistor melalui lubang-lubang yang ada, maka phototransistor akan mengalami saturasi dan akan menghasilkan suatu pulsa gelombang persegi. Susunan bagian dari rotary encoder dapat dilihat pada gambar. 2.3. berikut.

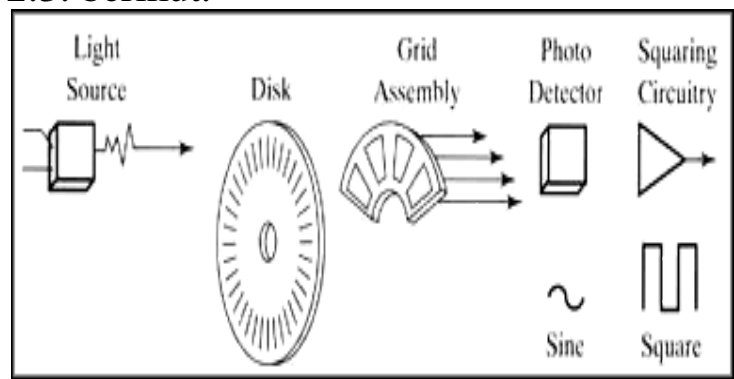

Gambar. 2.3. Blok penyusun rotary encoder[4].

\subsection{Arduino Uno}

Arduino Uno adalah board mikrokontroller berbasis ATmega328. Memiliki 14 pin input dari output digital dimana 6 pin input tersebut dapat digunakan sebagai output PWM dan 6 pin input analog, $16 \mathrm{MHz}$ osilator kristal, koneksi USB, jack power, ICSP header, dan tombol reset. Agar mikrokontroller dapat digunakan yaitu dengan menghubungkan Board Arduino Uno ke komputer dengan menggunakan kabel USB atau listrik dengan AC ke adaptor dc atau baterai. Bentuk 
Arduino Uno dapat dilihat pada gambar 2.4. berikut.

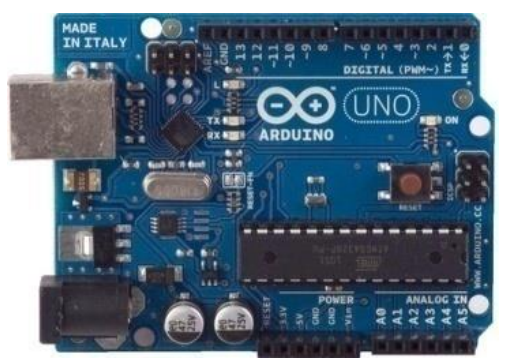

Gambar. 2.4. Modul Arduino Uno[1].

\subsection{Modul Data Logger}

Data logger merupakan data penyimpanan ke external memory atau ke SD Card, penggunaan data logger ini biasanya untuk menganalisa/mendapatkan data dari suatu kondisi di tempat tertentu. Misalnya untuk perubahan suhu per satuan waktu di tempat tertentu. Bentuk dari Aduino data logger dapat dilihat pada gambar. 2.5. berikut.

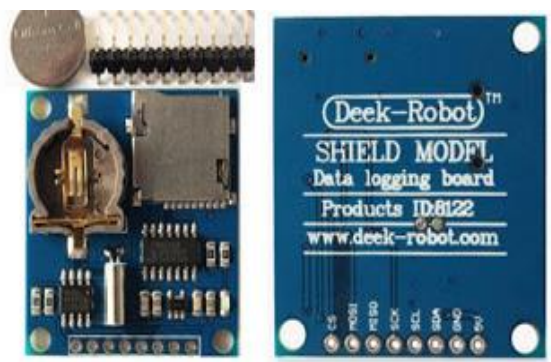

Gambar 2.5. Arduino data logger[13].

Selain data logger, modul ini juga langsung ada RTC (Real Time Clock) untuk pencatat waktu. Untuk konfigurasi data logger dengan arduino menggunakan koneksi SPI, maka untuk pin di arduino UNO bisa menggunakan pin yang ditunjukan pada gambar. 2.6. sebagai berikut:
a. MOSI - pin 11
b. MISO - pin 12
c. CLK - pin 13
d. $\mathrm{CS}$ - pin 10

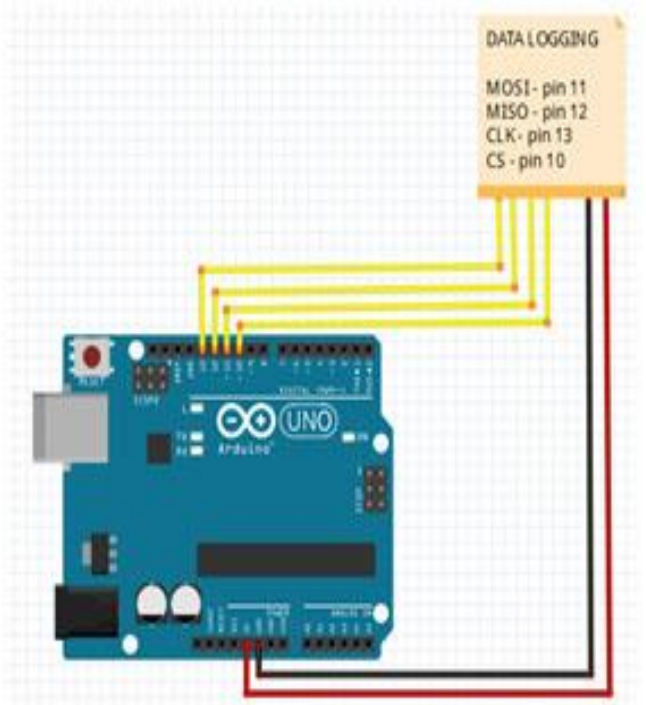

Gambar. 2.6.Konfigurasi data logger dengan arduino[13].

\section{METODELOGI PENELITIAN}

\subsection{Blok Diagram}

Secara garis besar sistem yang dibuat dapat dilihat pada gambar 3.1. berikut :

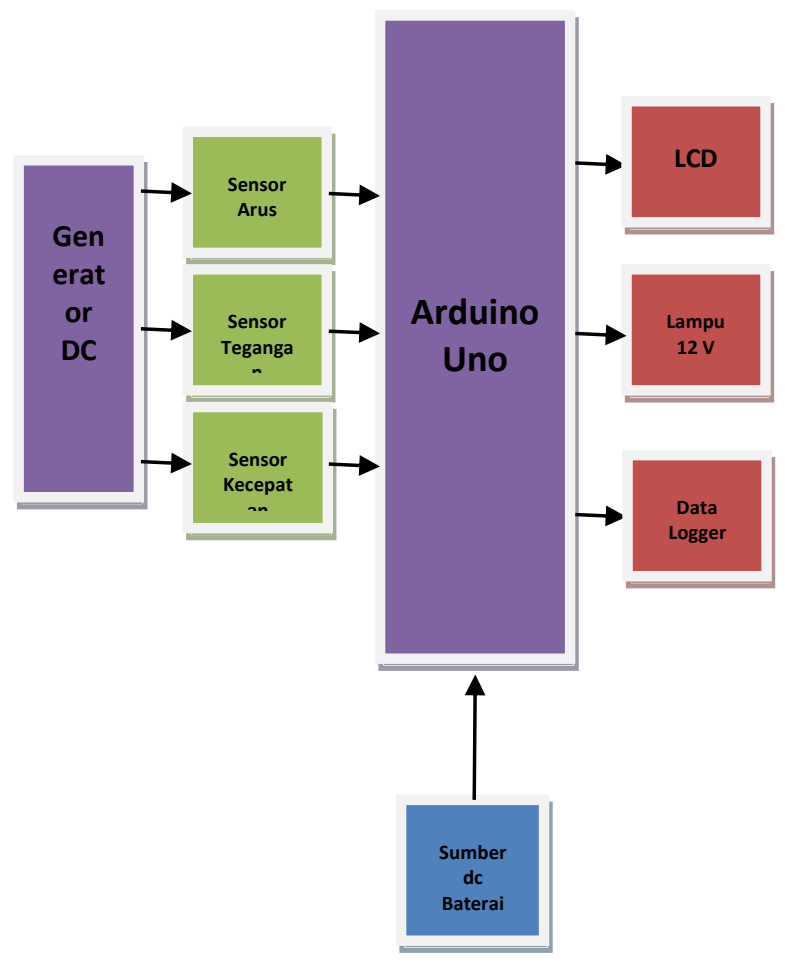

Gambar.3.1. Blok diagram sistem 


\subsection{Metode Kerja}

Proses penyelesaian penelitian ini melalui beberapa langkah yang dilakukan, secara umum langkahlangkah tersebut digambarkan dalam diagram alir yang terlihat pada gambar 3.2. di bawah ini :

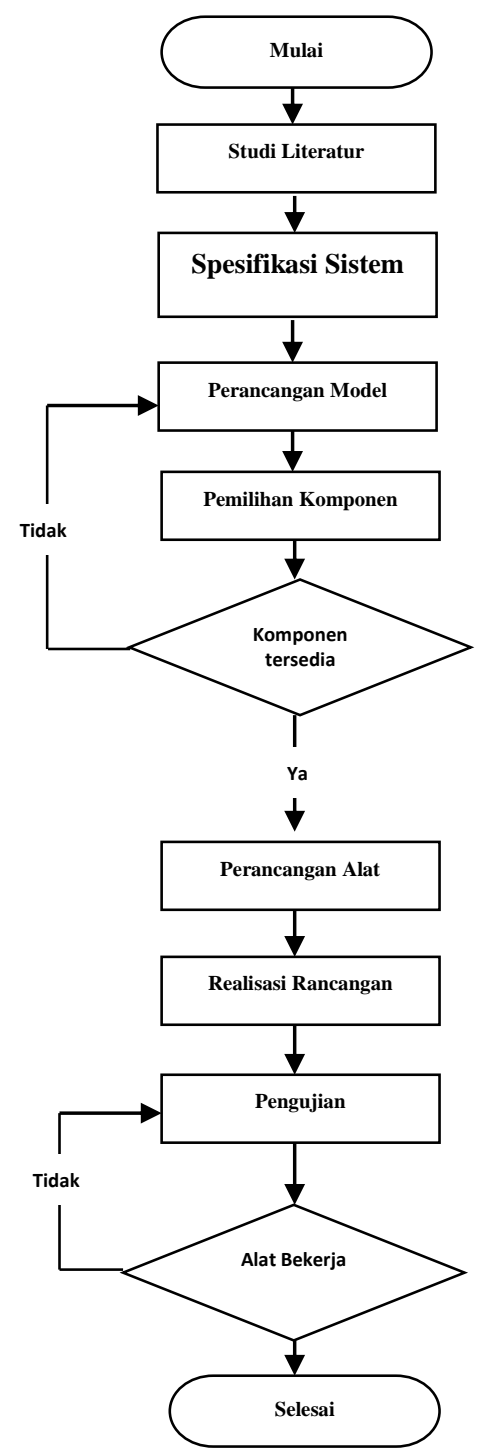

Gambar. 3.2. Diagram alir penelitian

\subsubsection{Studi Literatur}

Pada studi literatur, dilakukan pengumpulan informasi dan literatur yang menunjang penelitian antara lain:

a. Mempelajari prinsip generator dc yang akan digunakan pada prototype.

b. Mempelajari mikrokontroler, dan modul-modul pendukung yang terdapat pada Arduino. c. Mempelajari penggunaan Rotary Encoder yang berfungsi sebagai sensor putaran pada jangkar generator.

d. Mempelajari metode pembagi tegangan yang berfungsi sebagai sensor tegangan.

e. Mempelajari ACS712 yang berfungsi sebagai pembacaan nilai arus atau sensor arus.

f. Mempelajari penggunaan LCD $2 \times 16$ yang berfungsi untuk menampilkan nilai rpm, arus, dan tegangan.

g. Mempelajari penggunaan Arduino Data Logging RTC Shield yang berfungsi sebagai tempat Multi Media Card (MMC) yaitu untuk menyimpan nilai-nilai yang didapatkan.

\subsubsection{Spesifikasi Rancangan}

Sistem yang akan direalisasikan, yaitu untuk mendapat hubungan tegangan generator dan arus generator terhadap kecepatan putarrotor generator. Nilai-nilai yang didapat dalam pengambilan data akan dibandingkan dengan data perhitungan menggunakan rumus E.M.F Generator yaitu sebagai berikut[2]:

emf generator $=\frac{d \varphi}{d t}($ volt $)$

Perpotongan fluks dalam satu rotasi $=d \varphi=$ $\varphi P(W b)$

waktu untuk satu putaran, $d t=60 / N$

Jadi:

$$
\begin{aligned}
& \text { emf }=\frac{d \varphi}{d t}=\frac{\varphi P N}{60} \text { volt } \\
& \text { emf }=\frac{\varphi P N}{60} \text { volt }
\end{aligned}
$$

Keterangan[2] :

○ $\varphi=$ nilai fluks

○ $\quad \mathrm{P}=$ jumlah kutup

- $\mathrm{N}=$ putaran jangkar permenit (rpm)

$\circ \quad \mathrm{Emf}=$ tegangan generator

Untuk mencari hubungan kecepatan putaran rotor generator terhadap tegangan dan arus yang dihasilkan mempunyai dua tahapan sebagai berikut:

a. Mencari hubungan rpm dengan tegan (volt) dengan persamaan 


$$
\begin{aligned}
& \text { emf }=\frac{d \varphi}{d t}=\frac{\varphi P N}{60} \text { volt } \\
& \text { emf }=\frac{\varphi P N}{60} \text { volt } \ldots \ldots \ldots . . .
\end{aligned}
$$

b. Mencari hubungan rpm dengan arus (ampere) dengan persamaan terbagi menjadi 2 tahapan:

- Mencari Arus pada beban lampu

$$
\begin{aligned}
& P=V \times I \\
& I=\frac{P}{V} \cdots \cdots
\end{aligned}
$$

- Mencari nilai R (ohm) pada beban lampu

$$
R=\frac{V}{I}
$$

\subsubsection{Spesifikasi Alat}

Spesifikasi alat yang digunakan untuk membuat prototype ini adalah :

a. Baling-baling berukuran 16 inch dan memiliki 3 buah blade, berfungsi untuk memutar jangkar generator, yaitu dengan cara mengkopel baling-baling pada bagian ujung rotor. Saat balingbaling berputar karena tekanan angin maka jangkar generator akan berputar sehingga generator dapat menghasilkan tegangan.

b. Generator dc dengan spesikasi 12 volt dengan kecepatan putaran rotor 500 rpm saat tanpa beban dan daya yang mampu dihasikan sebesar 15 watt.

c. Sensor rotary encoder berfungsi untuk membaca puataran yang dihasilkan pada jangkar generator.

d. Menggunakan ACS712 5A, berfungsi sebagai pembaca arus yang dihasilkan generator saat ada beban lampu.

e. Rangkaian pembagi tegangan digunakan sebagai sensor tegangan, yaitu berfungsi sebagai pembaca tegangan yang dihasilkan generator.

f. Menggunakan Liquid Crystal Display (LCD) $16 \times 2$ sebagai penampil data.

g. Menggunakan modul Arduino Data Logging RTC Shield yang berfungsi untuk menyimpan data yang telah diolah pada mikrokontroler.

h. Device pengendali menggunakan modul Arduino Uno, berfungsi untuk membaca masukan dari sensor kecepatan, sensor tegangan dan sensor arus. Untuk menampilkan nilai rpm, tegangan, dan arus pada LCD dan data yang telah terbaca akan disimpan pada Arduino Data Logging RTC Shield.

\subsection{Diagram Alir Kerja Alat}

Rancangan kerja prototype ini melalui beberapa langkah, yaitu start, inisialisasi arduino, kemudian pembacan sensor sampai end (selesai). Untuk diagram alir kerja alat dapat dilihat pada gambar. 3.3. berikut.

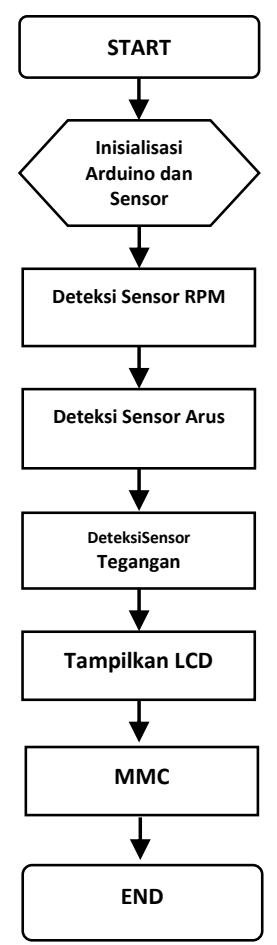

Gambar. 3.3. Diagram Alir Kerja Alat

\section{HASIL DAN PEMBAHASAN}

\subsection{Prinsip Kerja Alat}

Penelitian ini adalah membuat prototype generator dc yang digerakan oleh angin untuk mendapatkan kecepatan putar rotor generator nilai tegangan, dan arus yang dihasilkan generator tersebut. Prinsip dari prototype ini yaitu generator dikopel dengan baling-baling menggunakan beban lampu sepeda motor 12Volt, dengan berputarnya baling-baling maka generator menghasilkan nilai tegangan (Volt), arus (Ampere), kecepatan putaran (rpm), sehingga lampu dapat menyala. Selanjutnya nilai-nilai tersebut ditampilkan 
pada LCD 2 x 16 dan datanya disimpan secara berkala pada MMC (Multi Media Card) yang terpasang pada RTC Data Logger.

\subsection{Konstruksi Alat Keseluruhan}

Konstruksi alat keseluruhan dapat dilihat pada gambar 4.1.

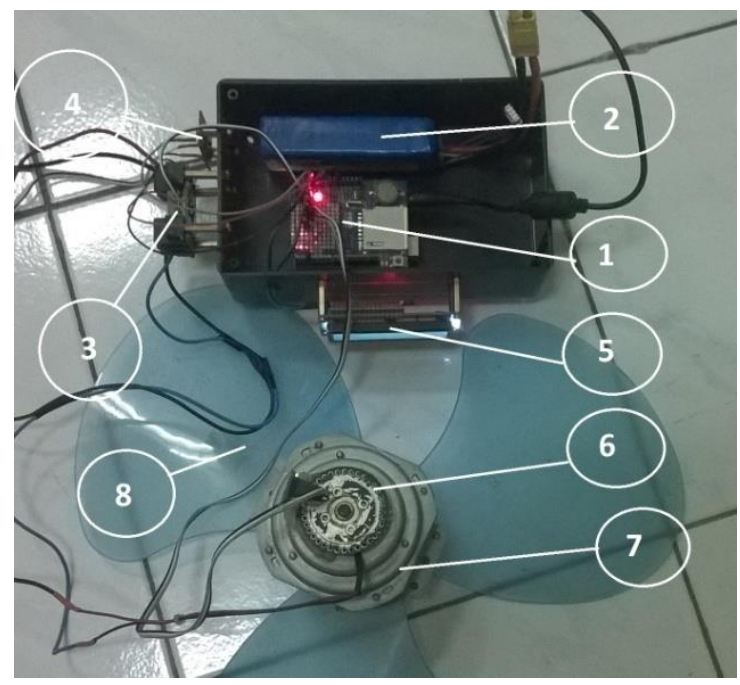

Gambar 4.1. Konstruksi alatprototype

Keterangan gambar 4.1:

1. Arduino Uno dan Data LoggerRTC

Shield

2. Baterry lippo 11 Volt

3. Sensor Arus

4. Sensor Tegangan

5. LCD $2 \times 16$

6. Sensor rpm Rotary Encoder

7. Generator DC $12 \mathrm{~V}, 500 \mathrm{rpm}$ tanpa beban

8. Baling-baling kipas 16 inch

\subsection{Hasil Uji Data Alat}

Pengujian prototype ini menggunakan sepeda motor dengan kecepatan yang bervariasi, yang dilakuakan 6 kali pengujianpada kecepatan $10 \mathrm{~km} / \mathrm{jam}$, $20 \mathrm{~km} / \mathrm{jam}, 30 \mathrm{~km} / \mathrm{jam}, 40 \mathrm{~km} / \mathrm{jam}, 50 \mathrm{~km} / \mathrm{jam}$, dan $60 \mathrm{~km} / \mathrm{jam}$. Data diambil persepuluh setiap kali pengujian.dataseluruh hasil pengujian dapat dilihat pada tabel. 4.1. berikut.

Tabel.4.1. Hasil Uji Data Alat

\begin{tabular}{|c|c|c|c|}
\hline $\begin{array}{c}\text { Kecepatan } \\
\text { Sepeda } \\
\text { Motor } \\
(\mathrm{km} / \mathrm{jam})\end{array}$ & $\begin{array}{c}\text { Rpm } \\
\text { Generator }\end{array}$ & $\begin{array}{c}\text { Tegangan } \\
(\mathrm{V}) \\
\text { Generator }\end{array}$ & $\begin{array}{c}\text { Arus (A) } \\
\text { Generator }\end{array}$ \\
\hline 10 & 0 & 0 & 0 \\
\hline 20 & 0 & 0 & 0 \\
\hline
\end{tabular}

\begin{tabular}{|c|c|c|c|}
\hline $\begin{array}{c}\text { Kecepatan } \\
\text { Sepeda } \\
\text { Motor } \\
(\mathrm{km} / \mathrm{jam})\end{array}$ & $\begin{array}{c}\text { Rpm } \\
\text { Generator }\end{array}$ & $\begin{array}{l}\text { Tegangan } \\
\text { (V) } \\
\text { Generator }\end{array}$ & $\begin{array}{l}\text { Arus (A) } \\
\text { Generator }\end{array}$ \\
\hline \multirow{10}{*}{30} & 484 & 2.69 & 0.77 \\
\hline & 475 & 2.36 & 0.77 \\
\hline & 479 & 2.42 & 0.76 \\
\hline & 474 & 2.52 & 0.77 \\
\hline & 470 & 2.47 & 0.78 \\
\hline & 479 & 2.52 & 0.77 \\
\hline & 459 & 2.31 & 0.76 \\
\hline & 473 & 2.42 & 0.76 \\
\hline & 478 & 2.47 & 0.76 \\
\hline & 478 & 2.52 & 0.76 \\
\hline \multirow{10}{*}{40} & 713 & 5.26 & 0.91 \\
\hline & 712 & 5.05 & 0.91 \\
\hline & 711 & 5.00 & 0.92 \\
\hline & 715 & 5.05 & 0.92 \\
\hline & 714 & 5.10 & 0.92 \\
\hline & 714 & 5.05 & 0.92 \\
\hline & 728 & 5.32 & 0.93 \\
\hline & 716 & 5.05 & 0.92 \\
\hline & 730 & 5.26 & 0.93 \\
\hline & 789 & 5.59 & 0.96 \\
\hline \multirow{10}{*}{50} & 866 & 6.82 & 1.04 \\
\hline & 868 & 6.77 & 1.05 \\
\hline & 872 & 7.04 & 1.05 \\
\hline & 880 & 7.14 & 1.06 \\
\hline & 879 & 6.98 & 1.05 \\
\hline & 882 & 7.14 & 1.05 \\
\hline & 887 & 7.09 & 1.06 \\
\hline & 879 & 6.82 & 1.06 \\
\hline & 879 & 6.98 & 1.05 \\
\hline & 880 & 7.14 & 1.05 \\
\hline \multirow{10}{*}{60} & 1105 & 9.45 & 1.16 \\
\hline & 1131 & 9.72 & 1.26 \\
\hline & 1194 & 10.53 & 1.29 \\
\hline & 1189 & 10.74 & 1.28 \\
\hline & 1180 & 10.74 & 1.28 \\
\hline & 1179 & 10.73 & 1.27 \\
\hline & 1189 & 10.74 & 1.27 \\
\hline & 1180 & 10.31 & 1.27 \\
\hline & 1303 & 11.12 & 1.42 \\
\hline & 1379 & 11.60 & 1.43 \\
\hline
\end{tabular}

\subsection{Nilai Uji Rata-rata Kecepatan Sepeda Motor 10 Km/jam - 60 Km/jam}

Dari tabel. 4.1. didapatkan nilai uji rata-rata pengujian yang didapatkan dengan cara menjumlahkan semua data pengujian setiap kecepatan sepeda motor dibagi dengan jumlah data yang diambil. Nilai uji rata-rata dapat dilihat pada tabel. 4.2. berikut. 
Tabel. 4.2. Nilai Uji Rata-rata

\begin{tabular}{|c|c|c|c|}
\hline $\begin{array}{c}\text { Kecepatan } \\
\text { Sepeda } \\
\text { Motor } \\
(\mathrm{km} / \mathrm{jam})\end{array}$ & Rpm & $\begin{array}{c}\text { Teganga } \\
(\mathrm{V})\end{array}$ & Arus (A) \\
\hline 10 & 0 & 0 & 0 \\
\hline 20 & 0 & 0 & 0 \\
\hline 30 & 474 & 2.47 & 0.77 \\
\hline 40 & 724 & 5.17 & 0.92 \\
\hline 50 & 877 & 6.99 & 1.05 \\
\hline 60 & 1202 & 10.57 & 1.29 \\
\hline
\end{tabular}

Data pada tabel. 4.2. di atas digunakan untuk mencari persamaan garis hubungan kecepatan sepeda motor dengan kecepatan putaran rotor generator, hubungan kecepatan rotor generator dengan arus generator, dan hubungan kecepatan rotor generator dengan tegangan generator.

\subsection{Hubungan Antara Kecepatan Sepeda Motor Terhadap Puatran Rotor Generator}

Dari nilai rata-rata keseluruhan didapat grafik hubungan antara kecepatan sepeda motor dengan kecepatan putar rotor generator dengan menggunakan spesifikasi baling-baling 3 buah blade dengan diameter 16 inch. Grafik dapat dilihat pada gambar. 4.2.berikut.

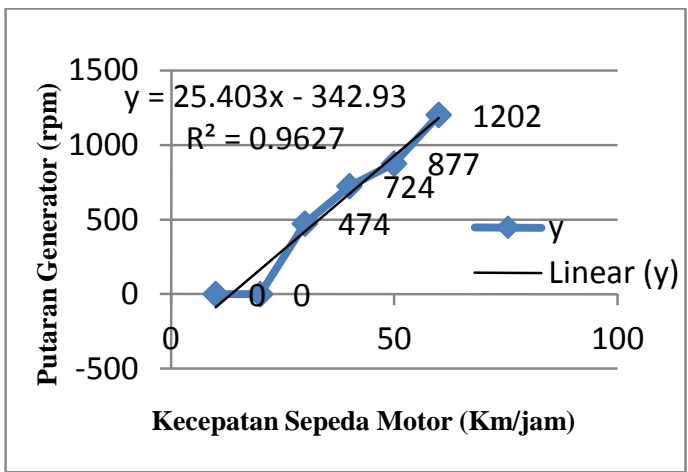

Gambar. 4.2. Grafik hubungan antara kecepatan sepeda motor terhadap putaran rotor generator.

Grafik pada gambar. 4.2 di atas dapat dilihat bahwa hubungan antara tegangan yang dihasilkan generator terhadap kecepatan sepeda motor yang bervariasi adalah linier dan dari grafik di atas didapat persamaan garis yaitu: $\quad y=25,40 x-342,9$ (berlaku saat kecepatan $\geq 30 \mathrm{Km} / \mathrm{jam}$ ) dengan nilai regresinya adalah 0,962 . Nilai regresi ini dihitung dengan merata-ratakan besarnya nilai $\mathrm{R}^{2}$ yang dihasilkan pada saat pengolahan data.

\subsection{Hubungan Antara Putaran Rotor Generator dengan Tegangan \\ Generator}

Dari tabel. 4.2. di atas didapatkan hubungan antara putaran rotor generator dengan tegangan generator. Grafik dapat dilihat pada gambar. 4.3. berikut.

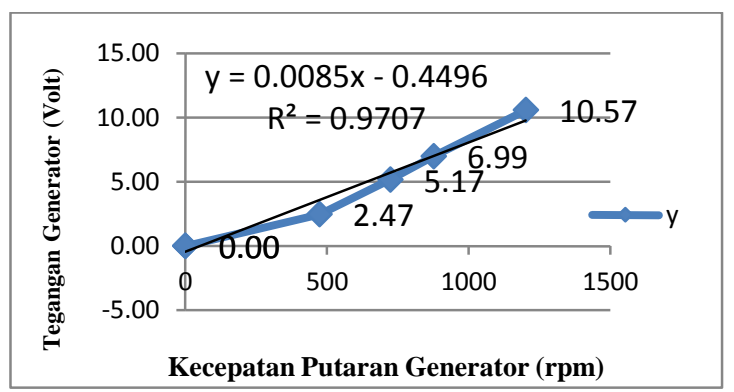

Gambar. 4.3. Hubungan antara putaran rotor generator dengan tegangan generator

Grafik pada gambar. 4.3. di atas dapat dilihat bahwa hubungan antara tegangan yang dihasilkan generator terhadap kecepatan putaran rotor generator (rpm)yang bervariasi adalah linier dan dari grafik di atas didapat persamaan garis yaitu: $y=0,008 x-0,449$ dengan nilai regresinya adalah 0,970 .

\subsection{Hubungan Antara Putaran Rotor Generator dengan Arus Generator}

Dari tabel. 4.2. di atas didapatkan hubungan antara putaran rotor generator dengan arus generator. Grafik dapat dilihat pada gambar. 4.4. berikut.

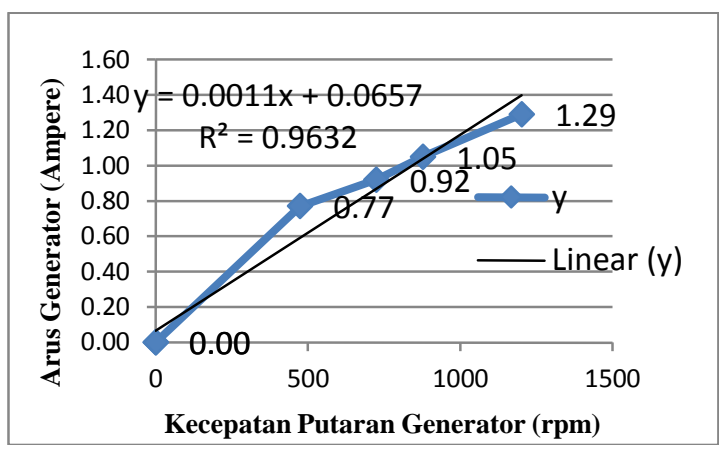

Gambar. 4.4. Grafik hubungan antara kecepatan putaran rotor generator dengan arus generator.

Grafik pada gambar. 4.4 di atas dapat dilihat bahwa hubungan antara tegangan yang dihasilkan generator terhadap kecepatan putaran generator yang bervariasi adalah linier 
dan dari grafik di atas didapat persamaan garis yaitu: $y=0,001 x+0,065$ dengan nilai regresinya adalah 0,963 .

\subsection{Perbandingan Tegangan Uji Dengan Perhitungan Terhadap Kecepatan Rotor Generator.}

Untuk melihat kinerja prototype dilakukan pengujian data hasil perhitungan. Hasil perbandingan nilai tegangan uji dengan tegangan perhitungan dapat dilihat pada gambar 4.5. berikut.

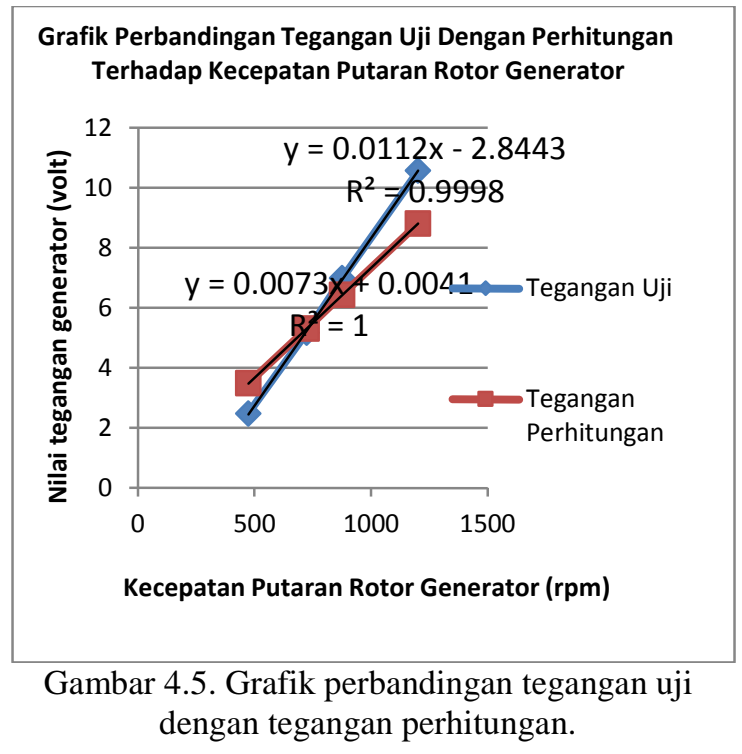

Grafik pada gambar. 4.5. adalah perbandingan tegangan uji dengan perhitungan terhadap rpm generator. Dari grafik di atas juga dapat diketahui bahwa perbandingan tegangan uji dengan perhitungan terhadap rpm generator yang bervariasi adalah linier. Grafik di atas didapat persamaan garis yaitu: persamaan garis pada tegangan uji terhadap putaran rotor generator (rpm) adalah $y=$ $0,007 x+0,004$ dengan nilai regresinya adalah 1. Sedangkan untuk persamaan garis pada tegangan dengan perhitungan $\mathrm{y}=0,011 \mathrm{x}$ - 2,844 dengan nilai regresinya adalah 0,999 . Sedangkan untuk rata-rata persentase perbandingan nilai tegangan antara teganan uji dan tegangan perhitungan adalah 15,04\%. Dari rata-rata persentase yang didapat terlihat bahwa prototype ini belum dapat bekerja secara maksimal, hal ini dikarenakan pembacaan pada sensor rotary encoder saat putaran rendah $(40 \mathrm{~km} / \mathrm{jam})$ kurang akurat.

\subsection{Perbandingan Nilai Arus Uji dengan Arus Perhitungan Terhadap Kecepatan Putaran Rotor Generator}

Hubungan perbandingan nilai arus uji dengan nilai arus perhitungan dilakukan untuk mengetahui kinerja alat.Nilai arus uji dengan arus perhitungan dapat dilihat pada gambar 4.6. berikut.

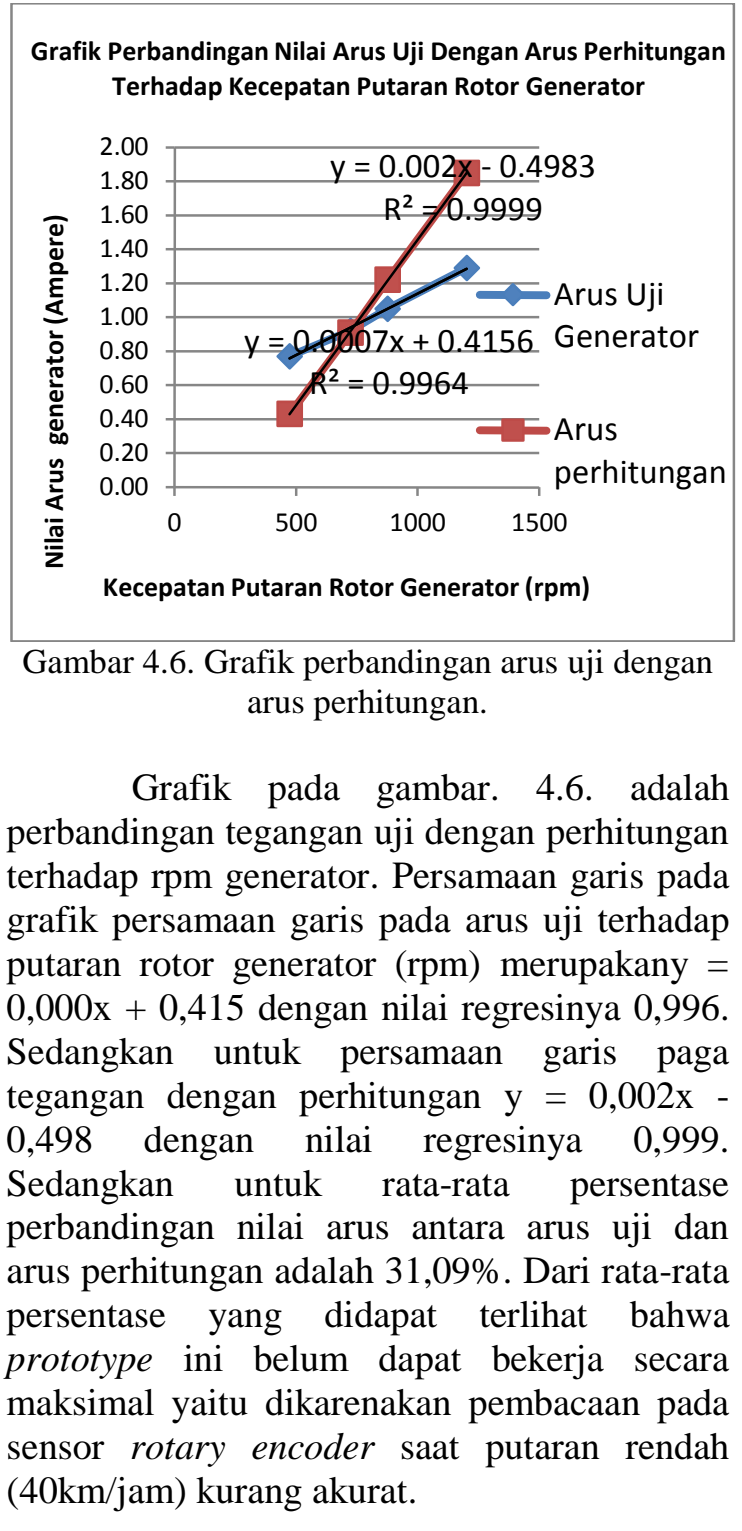




\section{KESIMPULAN DAN SARAN}

\subsection{Kesimpulan}

Kesimpulan dari hasil analisis dan pembahasan adalah :

1. Penelitian ini membuart sebuah prototype generator dengan penggerak tenaga angin yang telah diuji pada variasi $10 \mathrm{~km} / \mathrm{jam}-60$ $\mathrm{km} / \mathrm{jam}$.

2. Pada saat kecepatan $10 \mathrm{~km} / \mathrm{jam}$ dan $20 \mathrm{~km} / \mathrm{jam}$ saat kondisi berbeban, baling-baling yang terkopel dengan generator belum dapat bergerak sehingga belum dapat mengeluarkan putaran, tegangan, dan arus generator.

3. Hubungan kecepatan putaran rotor generator terhadap kecepatan sepeda motor prototypedengan persamaan $y=25,40 x-342,9 \quad$ hanya berlaku pada kecepatan $\geq 30$ $\mathrm{Km} / \mathrm{jam}$.

4. Hubungan antara perbandingan tegangan uji dengan tegangan perhitungan terhadap kecepatan putaran rotor generator (rpm), prototypedengan persentase ratarata eror adalah $15,04 \%$ dan didapatkan persamaan $\mathrm{y}_{\mathrm{uji}}$ $=0,007 \mathrm{x}+0,004$ dan $\mathrm{y}_{\text {perhitungan }}=$ $0,011 \mathrm{x}-2,844$.

5. Hubungan antara perbandingan arus uji dengan arus perhitungan terhadap kecepatan putaran rotor pada generator (rpm),prototype dengan persentase rata-rata eror adalah $31,09 \%$ dan didapatkan persamaan $\mathrm{y}_{\mathrm{uji}}=0,000 \mathrm{x}+0,0415$ dan $\mathrm{y}_{\text {perhitungan }}=0,002 \mathrm{x}-0,498$. Dari persentase eror yang didapat memungkinkan prototype ini belum bekerja secara maksimal dikarenakan pembacaan pada sensor yang belum akurat.

\subsection{Saran}

Saran dari penilitian ini adalah :

1. Agar dapat mengoptimalkan prototype ini diperlukan generator dengan putaran rendah tetapi dapat menghasilkan tegangan dan arus yang besar. Juga diperlukan sensor dengan pembacaan yang akurat dan teliti
2. Prototype ini dapat digunakan untuk aplikasi lain yang menggunakan angin sebagai sumber utama penggerak putaran generator.

\section{DAFTAR PUSTAKA}

[1]. Arduino, Arduino ATmega 328, http://arduino.cc/en/Main, diakses pada tanggal 9 Januari 2015

[2]. Theraja, B. L., 'Electrical Technology', S. Chand \& Company Ltd, 1978

[3]. Generator, Generator Arus Searah, http://repository.usu.ac.id, diakses pada tanggal 25 Oktober 2015.

[4]. Laboratorium Konversi Energi Elektrik, Sekilas Rotary Encoder, ITB, Bandung, 2009

[5]. Laboratorium Teknik Pengukuran Elektrik, Modul Praktikum Rangkaian Listrik, Universitas Lampung, Bandar Lampung, 2010

[6]. Chapman, S. J, 'Electric Machinery Fundamentals', McGraw-Hill, 2005

[7]. Setiono Puji, Pemanfaatan Alternator Mobil Sebagai Pembangkit Listrik Tenaga Angin. Universitas Negeri Semarang, Semarang, 2006

[8]. Audli Ridho, Rancang Bangun Alat Ukur Portble 9 Titik Kecepatan Aliran Sungai (Open Channel) Nirkable Berbasis PC, Universitas Lampung, Bandar Lampung, 2014

[9]. Allegromicro, ACS712 Datasheet Allegro MicroSystems, diakses pada tanggal 9 Januari 2015

[10]. Suyanto Muhammad dan Widyastuti Naniek, Pemanfaatan Alternator DC Dengan Inverter Pada (PLTMh) Sebagai Penyedia Daya Listrik Produktif Di Dusun Singosaren Imogiri Yogyakarta, Universitas Kristen Stya Wacana, Yogyakarta, 2014

[11]. Prinsip Penyearah Tegangan Listrik 
Mesin Arus Searah (Komutasi),

http://www.narotama.ac.id, diakses pada

tanggal 15 Desember 2015

[12]. Petruzella, Frank D, Elektronik IndustrI, Jogjakarta, 1996

[13]. Arduino, Arduino Data Logger, http://www.arduino.web.id/, diakses pada tanggal 15 Desember 2015 